\title{
PENGARUH KONSEP DIRI DAN SIKAP MAHASISWA PADA MATEMATIKA TERHADAP HASIL BELAJAR MATA KULIAH MATEMATIKA DASAR
}

\author{
Nurma Tambunan \\ Program Studi Pendidikan Matematika, \\ FTMIPA, Universitas Indraprasta PGRI Jakarta. \\ e-mail:nurma_tbn@yahoo.co.id
}

\begin{abstract}
Abstrak: Pengaruh Konsep Diri dan Sikap Mahasiswa pada Matematika terhadap Hasil Belajar Mata Kuliah Matematika Dasar. Tujuan Penelitian ini adalah untuk mengetahui seberapa besar pengaruh konsep diri dan sikap mahasiswa pada matematika terhadap hasil belajar matematika. Metode Penelitian adalah Metode Survei Korelasional. Sampel penelitian ini diambil populasi terjangkau dengan teknik simple random sampling, yaitu sebanyak 98 mahasiswa. Instrumen yang digunakan dalam penelitian ini adalah instrumen angket, untuk mengukur variabel konsep diri dan variabel sikap mahasiswa pada matematika, serta instrumen tes, untuk mengukur hasil belajar matematika, khususnya mata kuliah matematika dasar. Setelah dilakukan uji coba, ketiga instrumen tersebut dinyatakan valid dan reliabel. Selanjutnya data yang diperoleh dianalisis secara deskriptif dan dilakukan uji persyaratan analisis, yang meliputi uji normalitas dan uji linieritas, yang hasilnya data berdistribusi normal dan regresi berpola linier, sehingga analisis selanjutnya menggunakan analisis statistik parametrik, yaitu menggunakan regresi ganda. Dari pengolahan data diperoleh hasil bahwa secara simultan konsep diri dan sikap mahasiswa pada matematika memberikan pengaruh positif dan signifikan terhadap hasil belajar matematika. Persamaan regresi yang terbentuk adalah $Y=39,653+0,432 X_{1}+0,045 X_{2}$. Hal ini dapat diartikan bahwa jika semakin baik konsep diri dan semakin baik sikap mahasiswa pada matematika, maka semakin tinggi hasil belajar matematikanya
\end{abstract}

\section{Kata Kunci: Konsep Diri, Sikap Mahasiswa, Hasil Belajar Matematika.}

\begin{abstract}
The Impact of Self Concept and Student's Attitude toward Mathematics on the Result of Learning Mathematics. This research is aimed to acknowledging the impacts of both self concept and student's attitude toward mathematics on the result of learning mathematics. The method used in this research is corrasional survey methode. Sample in this research is taken from affordable population by using simple random sampling from the number of population reach as many as 98 respondents. The instrument used is questionnaire on variables of self concept and student's attitude on mathematics and test instrument on variables of the result of learning mathematics. After all instrument valid and reliable, the data was analyzed descriptively after the data fulfill normality test and linnearity test and the result show that distribution of the data is normal and the pattern of regression is linear. So the analysis is continued to statistic parametric analysis. Actually the research used double regression analysis. The result show that in simultaneous self concept and student's attitude on mathematics give positive impacts and significant impacts on the result of learning mathematics with regression equation $\mathrm{Y}=39,653 \mathrm{X}_{1}+0,0045 \mathrm{X}_{2}$. It means that if self concept and student's attitude was good on mathematics, so the result of learning mathematics was good.
\end{abstract}

Keywords: Self Concept, Student's Attitude toward Mathematics, Result of Learning Mathematics. 


\section{PENDAHULUAN}

Pendidikan di Indonesia saat ini merupakan bagian yang sangat penting dan membutuhkan perhatian yang lebih intensif dari banyak pihak. Hal ini dikarenakan fungsi dan tujuan pendidikan nasional yang tercantum dalam UU No. 20 tahun 2003 bab II pasal 3 adalah "Pendidikan Nasional berfungsi untuk mengembangkan kemampuan dan membentuk watak serta peradaban bangsa yang bermartabat dalam rangka mencerdaskan kehidupan bangsa, bertujuan untuk mengembangkan potensi agar menjadi manusia yang beriman dan bertakwa kepada Tuhan Yang Maha Esa, berakhlak mulia, sehat, berilmu, cakap, kreatif, mandiri, dan menjadi warga negara yang demokratis serta bertanggung jawab. Oleh karenanya pendidikan perlu dilaksanakan terpadu, serasi dan teratur serta pelaksanaan pendidikan didukung oleh partisispasi aktif pemerintah, berbagai kelompok masyarakat, pihak orangtua dan dewan kependidikan.

Pada hakikatnya, pendidikan merupakan kegiatan yang telah berlangsung seumur dengan manusia, artinya sejak adanya manusia telah terjadi usaha-usaha pendidikan dalam rangka memberikan kemampuan kepada subjek didik untuk dapat hidup dalam masyarakat dan lingkungannya. Sehingga dengan diberikannya pendidikan maka seorang anak didik sanggup untuk berbuat dan bertindak sebagai manusia yang berkepribadian sosial. Pendidikan juga dipandang sebagai situasi yang dapat menolong individu yang mengalami perubahan suatu proses, dengan demikian pendidikan dipandang penting sebagai pelaku perubahan dan perkembangan dalam masyarakat. Dalam proses belajar mengajar yang sedang berlangsung ataupun yang sudah selesai diajarkan, masih sering dijumpai sebagian mahasiswa yang belum mengerti dan memahami materi yang disampaikan oleh dosen.

Untuk mendukung proses belajar mengajar, seorang dosen harus memiliki dan menerapkan strategi tertentu supaya mahasiswa dapat belajar secara efektif. Hal ini bisa saja dilakukan dalam berbagai bentuk, misalnya pengelolaan pengajaran. Pengelolaan ini pun banyak sekali ragamnya, katakanlah lagi pengelolaan waktu belajar. Dapat dikatakan bahwa mempelajari sesuatu di waktu-waktu siang tentu sudah tidak efektif lagi, sehingga perlu dipikirkan bagaimana mengatur jadwal kuliah sehingga dapat diperoleh jadwal yang optimal dan dapat diterima oleh mahasiswa.

Keadaan mahasiswa yang kelelahan, mengantuk, lapar, tidak bergairah tentunya menimbulkan perasaan bosan, tidak konsentrasi dalam berpikir serta timbul frustasi, maka mahasiswa sering menunjukkan kecenderungan yang kurang baik. Contohnya, minta izin keluar kelas untuk buang air, mencuci tangan, mencuci muka, meminjam alat tulis pada teman, mengganggu teman dan perilaku lainnya.

Mata kuliah yang sukar, biasanya memerlukan konsentrasi tinggi dan untuk saat ini mata kuliah yang dianggap sukar oleh sebagian besar mahasiswa di Indonesia adalah mata kuliah berbau Matematika. Saat ini masih banyak mahasiswa yang mengalami kesulitan belajar matematika, karena matematika masih dianggap suatu pelajaran yang menakutkan, membosankan, tidak terlalu berguna dalam kehidupan seharihari, beban bagi mahasiswa karena bersifat abstrak, penuh dengan angka dan rumus. Selain itu, masih adanya sistem belajar yang menyamaratakan 
kemampuan mahasiswa, saat mahasiswa belum menguasai materi dasar, sudah ditambah dengan materi lain. Para mahasiswa pun cenderung tidak menyukai matematika karena dianggap sulit terutama dalam menyelesaikan soal-soal yang diberikan oleh dosen matematika. Apalagi jika dosen yang mengajar matematika sulit dipahami dalam pembawaan materi di dalam kelas, sehingga keadaan ini menambah ketidaksukaan mahasiswa pada matematika.

Memang diakui matematika merupakan mata kuliah yang tingkat kesulitannya cukup tinggi, memerlukan energi yang lebih ekstra dibanding yang lain. Untuk itu, materi matematika harus diberikan dengan memperhatikan tingkat pemahaman mahasiswa dan penyampaiannya harus semenarik mungkin. Hal ini diharapkan dapat membangkitkan kesukaan mahasiswa pada matematika. Untuk itu, pemilihan metode mengajar, penggunaan alat bantu pengajaran, suasana lingkungan kelas dan faktor-faktor lainnya harus diatur sedemikian rupa sehingga membangkitkan semangat mahasiswa mempelajari matematika.

Hasil belajar matematika mahasiswa dapat dilihat apabila tujuantujuan pembelajaran yang telah ditetapkan dapat dicapai oleh mahasiswa, dan sebaliknya apabila sebagian besar mahasiswa tidak dapat mencapai tujuan-tujuan dari pembelajaran berarti hasil pembelajaran tidak tercapai. Pada dasarnya hasil belajar matematika mahasiswa dipengaruhi oleh beberapa faktor, diantaranya kemampuan mahasiswa dan kualitas mengajar dosen atau efektif tidaknya proses belajar mengajar dalam mencapai tujuan pengajaran.

Agar tujuan belajar dapat tercapai dengan optimal maka seorang dosen harus dapat memperhatikan beberapa aspek yang berhubungan dengan kegiatan belajar mengajar yang dilakukannya. Salah satu kemampuan yang harus dimiliki dosen adalah kemampuan penguasaan materi dan mampu mengajarkannya. Menurut Sudjana (2004: 58), "hasil penelitian menunjukkan bahwa kemampuan dosen dalam menguasai materi pelajaran dan mampu mengajarkannya memberikan sumbangan yang terbesar dibandingkan dengan kemampuan-kemampuan lainnya."

Sebenarnya, hasil belajar ini ditentukan oleh banyak faktor, yaitu faktor dosen, lingkungan kampus, lingkungan tempat tinggal, cara belajar mahasiswa, fasilitas belajar yang digunakan, faktor internal mahasiswa, dan lain sebagainya. Akan tetapi, seorang mahasiswa yang telah menyadari tugasnya sebagai seorang pembelajar seharusnya dapat menggunakan faktor-faktor yang ada untuk memaksimalkan hasil belajarnya.

Pada keseharian, ada berbagai peran yang dijalani oleh individu sebagai manusia, salah satunya adalah perannya sebagai seorang mahasiswa. Ada banyak sekali pekerjaan, tantangan, dan tuntutan yang dihadapi dan harus di jalankan oleh mahasiswa. Pekerjaan, tantangan dan tuntutan tersebut antara lain pembuatan berbagai macam tugas, laporan, makalah, maupun ujian yang merupakan suatu bentuk evaluasi bagi mahasiswa yang dilaksanakan secara rutin, dan juga tugas-tugas akademis lainnya. Misalnya saja jika mahasiswa dalam menghadapi ujian, mereka dapat mengendalikan tegangan saat menghadapi ujian, dan tetap tenang, maka tidak ada hal yang menghambatnya, setidaknya dari dalam dirinya ia sudah dapat menguasai kondisinya sendiri. Tapi jika mahasiswa memiliki perasaan takut akan kegagalan atau merasa panik dalam menghadapi 
ujian, walaupun ia memiliki motivasi untuk berprestasi, tetap saja mahasiswa akan mengalami kesulitan untuk dapat meraih prestasi yang maksimal.

Kehidupan manusia dapat berlangsung karena adanya hubungan timbal balik dengan lingkungan hidupnya. Dalam hubungan ini manusia dituntut untuk dapat menyesuaikan diri dengan lingkungannya. Penyesuaian ini mengakibatkan manusia lebih banyak mengubah diri dibanding mengubah lingkungan. Tanggapan individu yang sehat terhadap diri dan kehidupannya merupakan landasan dasar untuk dapat menyesuaikan diri. Faktor konsep diri perlu juga dipertimbangkan dalam menentukan berhasil tidaknya penyesuaian diri seseorang. Dengan kata lain konsep diri merupakan hal yang sangat mempengaruhi penyesuaian diri dan merupakan faktor penting dalam perkembangan diri seseorang.

\section{METODE}

Metode yang digunakan dalam penelitian ini adalah metode survei, dimana peneliti berusaha menggambarkan keadaan suatu populasi dengan menggunakan data yang diperoleh dari sampel. Metode ini sering digunakan dalam ilmu sosial, karena kemampuannya untuk memperkirakan suatu hasil yang mewakili suatu populasi apabila pengambilan sampel dilakukan dengan benar. Informasi dikumpulkan bisa dari responden dengan menggunakan kuesioner, yang berasal dari sebagian populasi untuk mewakili seluruh populasi. Atau untuk memperoleh fakta-fakta dan gejalagejala yang ada dan mencari keterangan secara faktual, baik tentang institusi atau lembaga tertentu.Untuk mempermudah memahami jalannya proses penelitian serta memahami isi dari laporan penelitian ini, maka konstelasi masalah yang akan diteliti diharapkan dapat tergambar dalam desain penelitian seperti tampak pada gambar 1 .

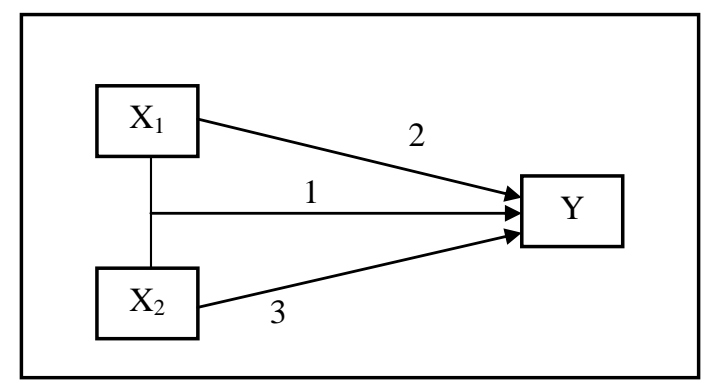

Gambar 1. Desain Penelitian

Keterangan:

$\mathrm{X}_{1}$ : Konsep Diri Mahasiswa

$\mathrm{X}_{2}$ : Sikap Mahasiswa pada Matematika

Y : Hasil Belajar Matematika

1 : Pengaruh Konsep Diri dan Sikap Mahasiswa pada Matematika Secara Bersama-sama terhadap Hasil Belajar Matematika

2 : Pengaruh Konsep Diri terhadap Hasil Belajar Matematika

3 : Pengaruh Sikap Mahasiswa pada Matematika terhadap Hasil Belajar Matematika

Populasi dalam penelitian ini adalah seluruh mahasiswa Sekolah Tinggi Ilmu Kesehatan Program Studi S1 Gizi dan populasi targetnya adalah seluruh mahasiswa peserta Matematika Dasar Sekolah Tinggi Ilmu Kesehatan Program Studi S1 Gizi. Populasi terjangkaunya adalah mahasiswa yang mengambil matematika dasar pada semester II reguler pagi pada tahun ajaran 2015/2016.

Untuk pengambilan sampel penelitian ini, mahasiswa-mahasiswa yang tergabung dalam populasi terjangkau diambil secara acak sebanyak 92 orang mahasiswa. Teknik sampling yang digunakan dalam penelitian ini adalah purposive 
sampling, artinya sampel diambil berdasarkan tujuan dan maksud tertentu, yaitu berdasarkan mata kuliah yang sedang diajarkan yaitu Matematika Dasar, dimana mata kuliah ini diajarkan pada mahasiswa Sekolah Tinggi Ilmu Kesehatan Program Studi S1 Gizi semester II. Sampel yang diambil adalah seluruh mahasiswa program reguler pagi.

Teknik analisis terhadap data hasil penelitian yang dalam hal ini berupa nilai prestasi belajar matematika serta perolehan total skor atas angket sikap dan task commitment mahasiswa dilakukan secara deskriptif dan inferensial. Secara deskriptif, data hasil penelitian dianalisis untuk skor mean, median, dan modus. Adapun maksud analisis skor mean, median, dan modus adalah untuk mendeskripsikan perolehan ukuran pemusatan data dari mahasiswa yang menjadi subjek penelitian. Secara inferensial, data hasil penelitian dianalisis menggunakan uji $\boldsymbol{F}$ dan uji $\boldsymbol{t}$, dengan terlebih dahulu diuji untuk persyaratan analisisnya yaitu uji normalitas, uji linearitas, dan uji multikolinearitas. Perhitungan data hasil penelitian secara keseluruhan dilakukan dengan menggunakan bantuan software SPSS.

\section{HASIL DAN PEMBAHASAN}

\section{Hasil Penelitian}

Data hasil penelitian ini dianalisis secara deskriptif dan inferensial. Secara deskriptif, data hasil penelitian ini ditampilkan dalam tabel 1 .

Tabel 1. Ringkasan Hasil Perhitungan Statistik Deskriptif

\begin{tabular}{lccc}
\hline \multicolumn{1}{c}{ Kelompok } & Mean & Median & Modus \\
\hline Prestasi Belajar Matematika & 75,06 & 75,00 & 75,00 \\
Konsep Diri Mahasiswa & 79,88 & 80,50 & 82,00 \\
Sikap Mahasiswa pada Matematika & 65,48 & 66,00 & 69,00 \\
\hline
\end{tabular}

Sumber: Data primer yang diolah

Berdasarkan tabel 1, diperoleh informasi untuk variabel prestasi belajar matematika peserta didik bahwa skor mean, median, dan modus relatif sama yang berada di satu titik yakni kisaran angka 75. Hal ini berarti, kurva distribusi frekuansi akan terbentuk simetris, yang maknanya adalah frekuensi dari skor prestasi belajar matematika yang tinggi dan rendah relatif sama. Kemudian berdasarkan tabel 1 juga, dapat diperoleh informasi bahwa skor mean, median, dan modus untuk variabel konsep diri mahasiswa tidaklah sama, dimana skor mean lebih kecil dari skor median, dan skor median lebih kecil dari skor modus. Hal ini berarti, kurva distribusi frekuensi akan terbentuk miring ke kiri, yang maknanya adalah akan ada frekuensi lebih rendah dari skor konsep diri mahasiswa yang tinggi dan frekuensi lebih tinggi dari skor konsep diri mahasiswa yang rendah. Informasi terakhir berdasarkan tabel 1 juga diperoleh bahwa skor mean, median, dan modus untuk variabel sikap mahasiswa pada matematika tidaklah sama, dimana skor mean lebih kecil dari skor median, dan skor median lebih kecil dari skor modus. Hal ini juga berarti, kurva distribusi frekuansi sikap mahasiswa pada matematika akan terbentuk miring ke kiri, yang maknanya adalah akan ada frekuensi lebih rendah dari skor tinggi untuk sikap 
mahasiswa pada matematika dan frekuensi lebih tinggi dari skor rendah sikap mahasiswa pada matematika.

Selanjutnya data hasil penelitian dianalisis secara inferensial untuk pengujian hipotesis, namun terlebih dahulu harus dilakukan uji persyaratan analisis data, yang meliputi uji normalitas, uji linearitas, dan uji multikolinearitas. Pengujian normalitas dilakukan untuk mengetahui normal atau tidaknya distribusi data yang akan dianalisis. Perhitungan untuk uji normalitas data dilakukan dengan uji Kolmogorof Smirnof. Kriteria pengujiannya adalah jika nilai probabilitas atau asymp. sig. (2-tailed) $>0,05 \quad($ dalam penelitian ini menggunakan $\alpha=5 \%$, maka dinyatakan data berasal dari populasi berdistribusi normal. Berdasarkan tabel 2, terlihat bahwa kelompok sampel yang diteliti memiliki nilai probabilitas atau asymp. sig. (2-tailed) $>0,05$, sehingga dapat disimpulkan bahwa data dari ketiga variabel dalam penelitian ini berasal dari populasi yang berdistribusi normal.

Tabel 2. Ringkasan Hasil Uji Normalitas

\begin{tabular}{lcc}
\hline \multicolumn{1}{c}{ Variabel } & $\begin{array}{c}\text { Kolmogorov- } \\
\text { Smirnov Z }\end{array}$ & $\begin{array}{c}\text { Asymp. Sig. } \\
\text { (2-tailed) }\end{array}$ \\
\hline Prestasi Belajar Matematika & 0,999 & 0,271 \\
Konsep Diri Mahasiswa & 0,761 & 0,608 \\
Sikap Mahasiswa pada Matematika & 0,665 & 0,769 \\
\hline
\end{tabular}

Sumber: Data primer yang diolah

Setelah uji normalitas data, selanjutnya dilakukan uji persyaratan analisis untuk uji linearitas. Pengujian linearitas dimaksudkan untuk mengetahui apakah dua variabel berpola linear antara satu sama lainnya. Dengan kata lain, uji linearitas dilakukan dalam rangka menguji model persamaan suatu variabel terikat atas suatu variabel bebas. Kriteria pengujiannya adalah kedua variabel dikatakan berpola linear jika nilai sig. linearity $<0,05$ (dalam penelitian ini menggunakan $\alpha=5 \%$ ). Oleh karena pada penelitian ini terdapat satu variabel terikat (Y) dan dua variabel bebas $\left(\mathrm{X}_{1}\right.$ dan $\left.\mathrm{X}_{2}\right)$, maka ada dua uji linearitas. Pertama uji linearitas $\mathrm{X}_{1}$ terhadap $\mathrm{Y}$, yang mana berdasarkan tabel 3, terlihat bahwa nilai sig. linearity $<0,05$, sehingga dapat disimpulkan bahwa terdapat hubungan yang linear antara konsep diri mahasiswa $\left(\mathrm{X}_{1}\right)$ dengan prestasi belajar matematika (Y). Yang kedua, uji linearitas $\mathrm{X}_{2}$ terhadap $\mathrm{Y}$, yang mana berdasarkan tabel 4 , terlihat bahwa nilai sig. linearity $<0,05$, sehingga dapat disimpulkan bahwa terdapat hubungan yang linear antara sikap mahasiswa pada matematika $\left(\mathrm{X}_{2}\right)$ dengan prestasi belajar matematika $(\mathrm{Y})$.

Tabel 3. Ringkasan Hasil Uji Linearitas Konsep Diri Mahasiswa terhadap Prestasi Belajar Matematika

\begin{tabular}{llccccc}
\hline & Model & Sum of Squares & Df & Mean Square & $F$ & Sig. \\
\hline 1 & Regression & 11822.546 & 1 & 11822.546 & 131.222 & .000 \\
& Residual & 11532.262 & 128 & 90.096 & & \\
& Total & 23354.808 & 129 & & & \\
\hline
\end{tabular}

Sumber: Data primer yang diolah 
Tabel 4. Ringkasan Hasil Uji Linearitas Sikap Mahasiswa pada Matematika terhadap Prestasi Belajar Matematika

\begin{tabular}{llccccc}
\hline & Model & Sum of Squares & Df & Mean Square & $F$ & Sig. \\
\hline 1 & Regression & 5338.305 & 1 & 5338.305 & 37.927 & .000 \\
& Residual & 18016.503 & 128 & 140.754 & & \\
& Total & 23354.808 & 129 & & & \\
\hline
\end{tabular}

Sumber: Data primer yang diolah

Setelah uji linearitas terpenuhi, selanjutnya dilakukan uji persyaratan yang terakhir yaitu uji multikolinearitas. Uji multikolinearitas dimaksudkan untuk mengetahui hubungan antar variabel bebas yaitu ada atau tidaknya hubungan yang kuat antara variabel kecerdasan spiritual dengan sikap peserta didik pada pelajaran matematika. Kriteria pengujiannya adalah kedua variabel bebas tidak terdapat masalah multikolinearitas jika nilai Variance Inflation Factor (VIF) < 10. Berdasarkan tabel 5, terlihat bahwa nilai Variance Inflation Factor (VIF) < 10 , berarti variabel terbebas dari asumsi klasik multikolinearitas atau dengan kata lain kedua variabel bebas tidak terdapat masalah multikolinearitas.
Tabel 5. Ringkasan Hasil Uji
Multikolinearitas

Collinearity Statistics

\begin{tabular}{llcc}
\multicolumn{2}{c}{ Model } & Tolerance & VIF \\
\hline 1 & Konsep Diri & .396 & 2.256 \\
& Sikap Mahasiswa & .396 & 2.256 \\
\hline
\end{tabular}

Sumber: Data primer yang diolah

Setelah semua uji persyaratan analisis terpenuhi, dilanjutkan dengan pengujian hipotesis, yaitu uji pengaruh konsep diri mahasiswa dan sikap mahasiswa pada matematika secara bersama-sama terhadap prestasi belajar matematika, uji pengaruh konsep diri mahasiswa terhadap prestasi belajar matematika, dan uji pengaruh sikap mahasiswa pada matematika terhadap prestasi belajar matematika.

Tabel 6. Ringkasan Hasil Uji Korelasi $X_{1}$ dan $X_{2}$ terhadap $Y$ Model Summary

\begin{tabular}{lcccc}
\hline Model & $R$ & $R$ Square & $\begin{array}{c}\text { Adjusted } R \\
\text { Square }\end{array}$ & $\begin{array}{c}\text { Std. Error of } \\
\text { the Estimate }\end{array}$ \\
\hline 1 & $.719^{\mathrm{a}}$ & .518 & .507 & 6.87392 \\
\hline Sumber: Data primer yang diolah
\end{tabular}

Tabel 7. Ringkasan Hasil Uji F untuk Pengujian Pengaruh Simultan $X_{1}$ dan $X_{2}$ terhadap $Y$

ANOVA ${ }^{\mathrm{b}}$

\begin{tabular}{llccccl}
\hline Model & & Sum of Squares & Df & Mean Square & $F$ & Sig. \\
\hline 1 & Regression & 2817.458 & 1 & 2817.458 & 42.970 & $.000^{\mathrm{a}}$ \\
& Residual & 5901.096 & 90 & 65.568 & & \\
& Total & 8718.554 & 91 & & & \\
\hline
\end{tabular}

Sumber: Data primer yang diolah 
Tabel 8. Ringkasan Hasil Uji $t$ untuk Pengujian Pengaruh $\mathrm{X}_{1}$ terhadap $\mathrm{Y}$ dan Pengaruh $\mathrm{X}_{2}$ terhadap $\mathrm{Y}$ Coefficients $^{\mathrm{a}}$

\begin{tabular}{llccccc}
\hline \multicolumn{7}{c}{ Unstandardized } \\
Model & \multicolumn{7}{c}{$\begin{array}{c}\text { Standardized } \\
\text { Coefficients }\end{array}$} & Coefficients & & \\
\hline 1 & (Constant) & 39.653 & 7.614 & & 5.208 & .000 \\
& KD & .432 & .074 & .685 & 5.857 & .000 \\
& SSM & .045 & .121 & .043 & .371 & .712 \\
\hline
\end{tabular}

Sumber: Data primer yang diolah

Korelasi ganda yang menghubungkan persamaan konsep diri, sikap mahasiswa pada matematika, dan prestasi belajar matematika diperoleh dari tabel 6. Berdasarkan tabel 6, diperoleh hasil korelasi konsep diri dan sikap mahasiswa pada matematika secara bersama-sama dengan prestasi belajar matematika adalah 0.744; yang berarti korelasi antara ketiga variabel tersebut tergolong kuat. Koefisien determinasinya sebesar 0,554 atau ada kontribusi sebesar $55,4 \%$ berupa pengaruh konsep diri dan sikap mahasiswa pada matematika secara bersama-sama terhadap prestasi belajar matematika. Pengujian signifikansi korelasi menggunakan koefisien sig, dimana sig $=0,000$; yang artinya korelasi antara ketiga variabel tersebut signifikan.

Selanjutnya adalah pengujian hipotesis regresi ganda $X_{1}$ dan $X_{2}$ terhadap $\mathrm{Y}$ dengan uji F. Adapun kriteria pengujiannya adalah $\mathrm{H}_{0}$ diterima jika $\mathrm{F}_{\text {hitung }}<\mathrm{F}_{\text {tabel }} \underline{\text { atau }} \mathrm{H}_{0}$ ditolak jika $F_{\text {hitung }}>F_{\text {tabel. }}$. Setelah dilakukan perhitungan, diperoleh nilai $\mathrm{F}$ seperti pada tabel 7. Berdasarkan tabel 7, diperoleh nilai $F_{\text {hitung }}=78,939$. Adapun dengan $\mathrm{dk}_{1}=2$ dan $\mathrm{dk}_{2}=127$ diperoleh nilai $F_{\text {tabel }}=3,067$. Oleh karena $\mathrm{F}_{\text {hitung }}>\mathrm{F}_{\text {tabel }}$ maka $\mathrm{H}_{0}$ ditolak. Hal ini berarti bahwa $\mathrm{H}_{0}$ (hipotesis nol) yang menyatakan tidak terdapat pengaruh yang signifikan konsep diri dan sikap mahasiswa pada matematika secara bersama-sama terhadap prestasi belajar matematika adalah ditolak. Dengan demikian, hipotesis pada penelitian ini yang berbunyi: "terdapat pengaruh yang signifikan konsep diri dan sikap mahasiswa pada matematika secara bersama-sama terhadap prestasi belajar matematika" adalah diterima. Dengan kata lain, dapat disimpulkan bahwa terdapat pengaruh yang signifikan konsep diri dan sikap mahasiswa pada matematika secara bersama-sama terhadap prestasi belajar matematika.

Adapun persamaan regresi ganda yang diperoleh berdasarkan hasil penelitian ini dapat disusun berdasarkan tabel 8. Berdasarkan tabel 8 , disusun persamaan regresi ganda $\widehat{Y}=39,653+$ $0,432 X_{1}+0,045 X_{2}$. Adapun persamaan regresi ganda tersebut dapat diinterpretasikan sebagai berikut: Konstanta sebesar 39,653 menyatakan bahwa jika tidak ada konsep diri dan sikap mahasiswa pada matematika maka prestasi belajar matematika mahasiswa diperoleh sebesar 39,653. Atau dengan kata lain prestasi belajar matematika peserta didik diperoleh sebesar 39,653 jika konsep diri dan sikap mahasiswa pada matematika diabaikan. 
Koefisien regresi $\mathrm{X}_{1}$ (konsep diri mahasiswa) sebesar 0,432 menyatakan bahwa setiap penambahan 1 satuan, konsep diri mahasiswa akan meningkatkan prestasi belajar matematika sebesar 0,432 dengan anggapan $\mathrm{X}_{2}$ (sikap mahasiswa pada matematika) tetap. Berlaku juga sebaliknya, jika konsep diri mahasiswa turun 1 satuan, maka prestasi belajar matematika diprediksi mengalami penurunan sebesar 0,432 dengan anggapan $\mathrm{X}_{2}$ (sikap mahasiswa pada matematika) tetap.

Koefisien regresi $\mathrm{X}_{2}$ (sikap mahasiswa pada matematika) sebesar 0,045 menyatakan bahwa setiap penambahan 1 satuan, sikap sikap mahasiswa pada matematika akan meningkatkan prestasi belajar matematika sebesar 0,045 dengan anggapan $\mathrm{X}_{1}$ (konsep diri mahasiswa) tetap. Berlaku juga sebaliknya jika sikap mahasiswa pada matematika turun 1 satuan, maka prestasi belajar matematika diprediksi mengalami penurunan sebesar 0,045 dengan anggapan $\mathrm{X}_{1}$ (konsep diri mahasiswa) tetap.

Kemudian nilai $\boldsymbol{t}$ seperti tampak pada tabel 8 , yang mana diperoleh nilai $\boldsymbol{t}_{\text {hitung sebesar 9,631. Pada taraf }}$ signifikansi 0,05 dengan $d k=\mathrm{n}-\mathrm{k}-$ $1=130-2-1=127 \quad$ diperoleh $\boldsymbol{t}_{\text {tabel }}=1,960$. Dengan demikian $\mathrm{H}_{0}$ ditolak karena $\left|\boldsymbol{t}_{\text {hitung }}\right|>\boldsymbol{t}_{\text {tabel }}$ $(9,631>1,960)$, hal ini berarti terdapat pengaruh yang signifikan konsep diri mahasiswa terhadap prestasi belajar matematika.

Berikutnya tertera pada tabel 8 , nilai $\boldsymbol{t}_{\text {hitung }}$ sebesar 3,697 . Pada taraf signifikansi 0,05 dengan $d k=\mathrm{n}-\mathrm{k}-$ $1=130-2-1=127 \quad$ diperoleh $\boldsymbol{t}_{\text {tabel }}=1,960$. Dengan demikian $\mathrm{H}_{0}$ ditolak karena $\left|\boldsymbol{t}_{\text {hitung }}\right|>\boldsymbol{t}_{\text {tabel }}$ $(3,697>1,960)$, hal ini berarti terdapat pengaruh yang signifikan sikap mahasiswa pada matematika terhadap prestasi belajar matematika.

\section{Pembahasan Hasil Penelitian}

1. Pengaruh Simultan Konsep Diri dan Sikap Mahasiswa pada Matematika Secara Bersama-sama terhadap Hasil Belajar Matematika

Dari hasil pengolahan data, diperoleh hasil korelasi antara variabel konsep diri dan sikap mahasiswa pada matematika secara bersama-sama dengan hasil belajar matematika adalah 0,719; yang berarti korelasi antara ketiga variabel tersebut tergolong kuat. Koefisien determinasinya sebesar 0,517 atau ada kontribusi sebesar $51,7 \%$ variabel konsep diri dan sikap mahasiswa pada matematika secara bersama-sama terhadap variasi hasil belajar matematika. Pengujian signifikansi korelasi menggunakan koefisien sig, dimana sig $=0,000$; yang artinya korelasi antara ketiga variabel tersebut signifikan.

2. Pengaruh Konsep Diri Mahasiswa terhadap Hasil Belajar Matematika

Dalam data hasil penelitian disimpulkan bahwa 51,7 \% hasil belajar matematika mahasiswa dipengaruhi oleh konsep diri, selanjutnya $48,3 \quad \%$ lainnya dipengaruhi oleh beragam faktor lainnya. Dengan demikian perlu adanya bimbingan Dosen dan orang tua agar mahasiswa dapat mengenal konsep diri yang efektif dan efisien serta mampu mendukung pencapaian tujuan pendidikan. Selanjutnya diperoleh pula kesimpulan bahwa $32,3 \%$ hasil belajar matematika mahasiswa dipengaruhi oleh sikap mahasiswa dan 67,7\% hasil belajar juga dipengaruhi oleh beragam faktor lain. Agar peningkatan hasil belajar 
matematika dapat lebih ditingkatkan, dibutuhkan pendekatan yang komprehensif dan terpadu agar persepsi negatif yang telah tertanam dalam diri mahasiswa segera diperbaiki, dan kondisi lingkungan belajar yang kurang kondusif dapat penanganan yang baik, bahkan perlu pula ada dukungan berkesinambungan dari dosen dan orangtua untuk membangan sikap terhadap matematika.

3. Pengaruh Sikap Mahasiswa pada Matematika terhadap Hasil Belajar Matematika

Pengaruh sikap mahasiswa terhadap hasil belajar dilakukan melalui uji t, dengan hipotesis berikut: dengan membandingkan antara nilai $t_{\text {hitung }}=$ $0,371<\mathrm{t}_{\text {tabel }}=1,662$ disimpulkan bahwa terdapat pengaruh yang tidak signifikan sikap mahasiswa terhadap hasil belajar Pengantar Dasar Matematika. Ini karena mahasiswa kurang mengisi instrumen penelitian dengan sejujur-jujurnya, dan masih memikirkan kepentingannya.

\section{SIMPULAN DAN SARAN}

\section{Simpulan}

Berdasarkan data hasil penelitian dan analisis perhitungan data yang sudah dilakukan di Sekolah Tinggi Ilmu Kesehatan Program Studi S1 Gizi, diperoleh simpulan hasil penelitian terdapat pengaruh yang signifikan konsep diri dan sikap mahasiswa pada matematika secara bersama-sama terhadap hasil belajar matematika, yaitu sebesar $37,3 \%$. Kemudian secara parsial terdapat pengaruh yang signifikan konsep diri mahasiswa terhadap hasil belajar matematika, yaitu sebesar 20,8\%; dan terdapat pengaruh yang signifikan sikap mahasiswa pada matematika terhadap hasil belajar matematika, yaitu sebesar $16,5 \%$.

\section{Saran}

Berdasarkan rangkaian penelitian yang runtun sudah dilaksanakan, melalui hasil penelitian ini, peneliti menaruh harapan tinggi untuk sistem pendidikan di Indonesia dapat terus membaik secara dinamis dari waktu ke waktu. Selain itu juga, peneliti berharap agar berbagai pihak di lingkungan pendidikan secara proaktif dapat merujuk pada berbagai hasil penelitian dalam upaya meningkatkan prestasi belajar matematika. melalui hasil penelitian ini, peneliti menyampaikan beberapa saran, antara lain bagi para peneliti lain yaitu dapat melaksanakan kajian penelitian yang sama, namun subjek penelitian berbeda. Hal ini dimaksudkan untuk lebih menegaskan lagi seperti apa konseptual yang mesti dibangun guna meningkatkan kualitas mutu pendidikan, khususnya prestasi belajar matematika.

Mahasiswa sebagai individu harus berusaha menghargai hidup dan kehidupannya, termasuk potensi yang dimilikinya sehingga dapat memiliki kepercayaan diri dalam menghadapi tantangan ke depan. Seluruh unsur pendidikan tinggi, meliputi dosen, pimpinan kampus, orang tua wali dan masyarakat sebagai orang terdekat mahasiswa juga harus berusaha memberikan penghargaan yang cukup kepada mahasiswa dalam rangka peningkatan konsep diri mahasiswa yang dampaknya akan meningkatkan hasil belajar Matematika Dasar.

Dosen sebagai unsur terdepan dalam proses pembelajaran harus berusaha untuk menampilkan proses pembelajaran yang menyenangkan, khususnya dalam mata kuliah pengantar dasar matematika. Hal ini tentunya akan meningkatkan motivasi dan minat 
mahasiswa belajar mata kuliah tersebut, yang dampaknya diharapkan dapat meningkatkan hasil belajarnya.

Seluruh elemen pendidikan, mahasiswa, orangtua, pendidik dan pemerintah harus mengupayakan agar mahasiswa memiliki sikap yang positif terhadap matematika dan memiliki konsep diri yang baik, karena dengan memiliki sikap yang positif terhadap matematika dan konsep diri yang baik diharapkan dapat meningkatkan hasil belajar matematika.

\section{DAFTAR RUJUKAN}

Burns, R.B. 1993. Konsep Diri: Teori, Pengukuran, Perkembangan dan Perilaku. Jakarta: Arcan.

Hurlock, E. B. 2001. Perkembangan Anak, Jilid 2. Jakarta: Erlangga.

Irwanto. 2002. Psikologi Umum. Jakarta: Prenhallindo.

John B. Biggs \& Philip J. Moore. 1983. Process of Learning, Third Edition. New York: Prentice Hall.

Kifli, B. dan Mustofa Usman. 1985. Prinsip-Prinsip Matematika. Bandung: Sinar Baru. Lubis, Z. 1998. Teori Belajar. Jakarta: STKIP Wijaya Bakti.

Mulyana, D. 2001. Ilmu Komunikasi Sebagai Suatu Pengantar. Bandung: Remaja Rosda Karya.

Nasution, A. H. 1980. Landasan Matematika. Jakarta: Bhratara Karya Aksara.

Nasution. 1992. Didaktik Azas-Azas Mengajar. Jakarta: Bumi Aksara.

Pudjijogyanti, C. R. 1988. Konsep Diri Dalam Pendidikan. Jakarta: Penerbit Arcan.

Purwanto, N. 1992. Psikologi Pendidikan,Bandung: Remaja Rosda Karya.

Rakhmat, J. 2003. Psikologi Komunikasi. Bandung: Remaja Rosda Karya.

Robbins, S. P. 2006. Perilaku Organisasi. Jakarta: Indeks.

Ruseffendi. 1990. Pengajaran Matematika Modern. Bandung: Tarsito.

Slameto. 1991. Belajar dan Faktor-faktor yang Mempengaruhinya. Jakarta: Rineka Cipta.

Solomon, M. R. 2004. Consumer Behavior: Buying, Having and Being. USA: Prentice Hall.

Sudjana, N. 2004. Penilaian Hasil Belajar Mengajar. Bandung: Remaja Rosda Karya.

Sujanto, A. 2004. Psikologi Kepribadian. Jakarta: Bumi Aksara

Suriasumantri, J. 1993. Filsafat Ilmu Sebuah Pengantar Populer. Jakarta: Pustaka Sinar Harapan.

Winkel, W. S. 1996. Psikologi Pendidikan dan Evaluasi Pendidikan. Jakarta: Gramedia. 